Asian-Australasian Journal of

Bioscience and Biotechnology

ISSN 2414-1283 (Print) 2414-6293 (Online)

www.ebupress.com/journal/aajbb

\title{
Article \\ Feeding frequency on the growth and production of endemic near-threatened Ompok pabda (Hamilton 1822) in pond setup
}

\author{
Md. Ashraful Islam ${ }^{1}$, Md. Abdus Samad ${ }^{1 *}$, Dipankar Paul ${ }^{2}$, Abdulla-Al-Asif ${ }^{3}$ and Amir Hossain ${ }^{4}$ \\ ${ }^{1}$ Department of Fisheries, Faculty of Agriculture, University of Rajshahi, Rajshahi-6205, Bangladesh \\ ${ }^{2}$ Upazila Fisheries Office, Department of Fisheries (DoF), Lalmonirhat, Bangladesh \\ ${ }^{3}$ Department of Animal Science and Fisheries, Faculty of Agricultural Science and Forestry, Universiti Putra \\ Malaysia Bintulu Sarawak Campus, Jalan Nyabau 97008, Bintulu, Sarawak, Malaysia \\ ${ }^{4}$ International Studies of Aquatic Tropical Ecology (ISATEC), Department of Biology, University \\ of Bremen, Bibliothekstraße 1, 28359 Bremen, Germany
}

*Corresponding author: Md. Abdus Samad, Department of Fisheries, Faculty of Agriculture, University of Rajshahi, Rajshahi-6205, Bangladesh, samad1413@yahoo.com

Received: 29 June 2021/Accepted: 21 August 2021/ Published: 31 August 2021

\begin{abstract}
Growth and production of near threatened Ompok pabda (Hamilton) were examined at different feeding frequencies in the present study. The experiment was conducted for four months in three earthen ponds from $1^{\text {st }}$ April to $31^{\text {st }}$ July 2018 at Tanore Upazila in Rajshahi district, Bangladesh. The experiment was performed using pabda, (Ompok pabda) fingerling (average) to study the effect of feeding frequency on growth performance. The study carried out considering three treatments, namely $T_{1}, T_{2}$, and $T_{3}$; while the feeding frequency was two times per day in treatment $T_{1}$, three times per day in treatment $T_{2}$, and four times per day in treatment $T_{3}$. Fish were fed considering three-stage of life span; these were fingerling stage, early growing stage, and growing stage. In the fry stage, the fishes were fed $20 \%$ feed, in the fingerlings stage the fish were fed $10 \%$ feed and in the growing stage, the fish were fed $8 \%$ feed of the body weight. The mean water temperature ranged between $27.13 \pm 2.10$ and $27.29 \pm 2.16{ }^{\circ} \mathrm{C}$ among treatments, while water transparency ranged between $31.91 \pm 1.58$ and $29.96 \pm 1.84 \mathrm{~cm}$. pH ranged between $7.62 \pm 0.14$ and $7.70 \pm 0.19$; while the mean dissolved oxygen was ranged between $5.35 \pm 0.11$ and $5.56 \pm 0.14$ among treatments. The final weight gain was found to be highest $(56.36 \pm 0.01)$ in the treatment $\mathrm{T}_{2}$ and lowest $(38.23 \pm 0.01)$ in the treatment $\mathrm{T}_{3}$. The SGR value was higher $(3.94 \pm 0.01)$ in the treatments $T_{2}$ followed by treatments $T_{1}$ and $T_{3}$. Net weight gain was significantly $(p<0.05)$ higher in feeding frequency three (56.36 \pm 0.1$)$, followed by feeding frequency four $(38.23 \pm 0.1)$ and feeding frequency two $(40.67 \pm 0.73)$. The FCR value ranged between 1.90 and 2.87 among treatments. The growth performance and specific growth rate were significantly $(\mathrm{p}<0.05)$ higher in feeding frequency three. The highest $\left(4049.1 \pm 0.1 \mathrm{~kg} / \mathrm{ha} / 120\right.$ days) production was observed in $\mathrm{T}_{2}$. Best cost benefit ratio was gained in treatment $\mathrm{T}_{2}$.
\end{abstract}

Keywords: IUCN listed; endemic species; pond aquaculture; feeding frequency; water quality

\section{Introduction}

A recent statistics suggested taht, 30 percent of freshwater species are extinct, endangered, or vulnerable across the globe (Dudgeon, 2010; Reeves et al., 2000). As a consequence, fish populations, especially those in inland open water regions, have progressively become threatened. According to the IUCN Bangladesh (2015), approximately 91 freshwater fish species in Bangladesh are severely or moderately endangered. As a result, establishing artificial breeding and large seed production methods for endangered fish species, such as Pabda, is critical for genetic conservation of their "gene pool" as well as biodiversity (Ompok pabda) (Chaklader et al., 2016; Hossain et al., 2015; Malakar et al., 2013; Purkayastha et al., 2012). 
This species may be found in a variety of freshwater environments in Bangladesh, with the bulk of its population concentrated in rivers, canals, beels, swamps, and ponds; however, it can also be found in India, Pakistan, Afghanistan, and Myanmar, with a broad geographic range (Alam et al., 2019; Chakraborty et al., 2010; Nahar and Halim, 2019; Singh et al., 2017b). In Bangladesh's freshwater, there are 260 indigenous fish species that have been discovered and documented, with one-third of the total being classified as small indigenous species (SIS), with pabda being one among them (Asadujjaman et al., 2013; Galib et al., 2010; Hossain, 2010; Kostori et al., 2011; Mondal et al., 2020a; Samad et al., 2013).

Moreover, some of the SIS species are important for their significant contribution of protein and minerals to the daily human diet, including for child, juvenile, maternal periods of women (Bogard et al., 2015b, 2015a; Byrd et al., 2021; Hossain et al., 1999; Kawarazuka and Béné, 2011; Reksten et al., 2020; Roos et al., 2003). Smallscale fishermen benefit from them as well, as they provide a significant source of money (Samad et al., 2013).

Pabda fish are found in the upper levels of water and are omnivorous in nature, with their major food items consisting of small fish, crustaceans, protozoans, algae, insects, parts of higher plants, and debris (Bhattacharjee and Pal, 2020; Chowdhury et al., 2020; Gupta, 2018; Roy et al., 2021; Singh et al., 2017b). Even though there are no specific nutritional requirements for aquaculture fish species, carbohydrates are always included in fish meals since they are a cheap source of energy and also serve as a pellet binder (Aaqillah-Amr et al., 2021; Apper-Bossard et al., 2013). They also requires 11 water soluble vitamins like A, D, E and K; along with vitamins there were 20 recognized inorganic mineral demands, which perform essential functions in the body (Hernandez and Hardy, 2020; Kwasek et al., 2020; Nölle et al., 2021; Prabhu et al., 2016).

The market price of fish is extremely important in commercial aquaculture; while the production of Thai Pangus, Pangasius hypophthalmus, is higher than that of many other species available on the market, its culture tendency is decreasing day by day as a result of the extremely low market price (Adnan et al., 2016; Ali et al., 2016; Hossain et al., 2019; Razeim et al., 2017; Shamsuzzaman et al., 2017; Zaman et al., 2017). In this context, Ompok pabda is a potential candidate for mass aquaculture practice as it fetches very high market value about 3-5 times higher than those of Pangas (Kohinoor et al., 2018, 2014). Because of its high market price and strong consumer demand, fish farmers are showing great interest in its culture. However, the lack of readily available fry is the most significant restriction. Despite the fact that Ompok pabda offers many benefits, little effort has been done in Bangladesh to promote the tradition of the pabda (Hossain et al., 2019).

It is possible that feeding frequency will result in the best FCR and weight growth of cultured fish species, resulting in the greatest utilization of the food (Billah et al., 2020). As a result, determining the optimum frequency of feeding for the target species in aquaculture is an essential step in developing a feeding plan that will result in the desired development of the fish. When compared to a single meal, several feedings result in a more effective use of the feed. Freshly born fry are often fed multiple times daily at an amount equal to 8-12 percent of their body weight. Fingerlings are fed between 5 and $10 \%$ of their body weight per day, split into two or more feedings, while brood fish are given 3 to $5 \%$ of their body weight per day, divided into two or more feedings (Paul et al., 2014; Singh et al., 2017a). During the warmer months, however, most catfish farmers feed their fish three times daily until they are satisfied, seven days a week (Li et al., 2004; Reigh et al., 2006). The optimal feeding frequency seems to be based on the size of the fish, and it has been shown that feeding more often is beneficial for greater development and survival in younger age groups (Başçıar and Çakmak, 2007; Billah et al., 2020; Cho et al., 2003; Eriegha and Ekokotu, 2019; Zakęś et al., 2006).

Capacity of A farmed fish to show its genetic prospective for growth and regeneration are influenced by a variety of variables, one of the most significant being nutrition. Factors like as fish behavior, feed quality, daily ratio size, feed intake, and water temperature all have a significant impact on their growth and development (Başçınar and Çakmak, 2007). In intensive culture systems, the feed cost accounts for about 40-60 percent of the operating expenses; thus, the economic sustainability of the culture operation is dependent on the feed and the frequency with which it is fed (Aderolu et al., 2010; Mohsin et al., 2012; Muya and Manyala, 2015). To put it another way, nutritionally balanced meals and sufficient feeding are the most important criteria for successful aquaculture operations (Boyd et al., 2020; Klinger and Naylor, 2012).

Previous study of feeding frequencies and production emphasized on different aquaculture species including, Labeo rohita, Catla catla, Labeo bata, Mystus cavasius, Clarias batrachus, Amblypharyngodon mola, Chela cachius, Puntius sophore, Heteropneustes fossilis, Notopterus chitala, Mylopharyngodon piceus (Hasan et al., 2002; Mondal et al., 2020a; Nahar et al., 2021; Samad et al., 2019, 2021; Samad and Imteazzaman, 2019; Samad et al., 2017a; Samad and Bhuiyan, 2017; Samad et al., 2017b; Samad et al., 2017a); while a single study described the feeding frequency of pabda fish from India but they dealt with the fry (juvenile stage), and no aquaculture feeding frequency of this species were found (Paul et al., 2014). The present study was undertaken 
with a view to study the growth response of the fish fed on a formulated standard diet at different feeding frequencies.

\section{Materials and Methods}

\subsection{Study location, pond facilities and periods}

The experiment was carried out in Tanor upazila in Rajshahi district, Bangladesh (Figure 1). The experiment was designed for rearing pabda $(O . p a b d a)$ in three treatments of each different feeding frequency, these were $\mathrm{T}_{1}, \mathrm{~T}_{2}$, and $\mathrm{T}_{3}$ for feeding fish twice a day, thrice a day and four time a day respectively where each experimental setup had three replications (Table 1). The stocking density were 74259 piece/ha for each ponds. At the beginning of the experiment, fish seed were released into each of the experimental ponds with an average length of $4.35 \pm 0.01 \mathrm{~cm}$ and an average weight of $0.51 \pm 0.01 \mathrm{~g}$ (on average). However, the study was conducted from $1^{\text {st }}$ April to $31^{\text {th }}$ July, 2018.

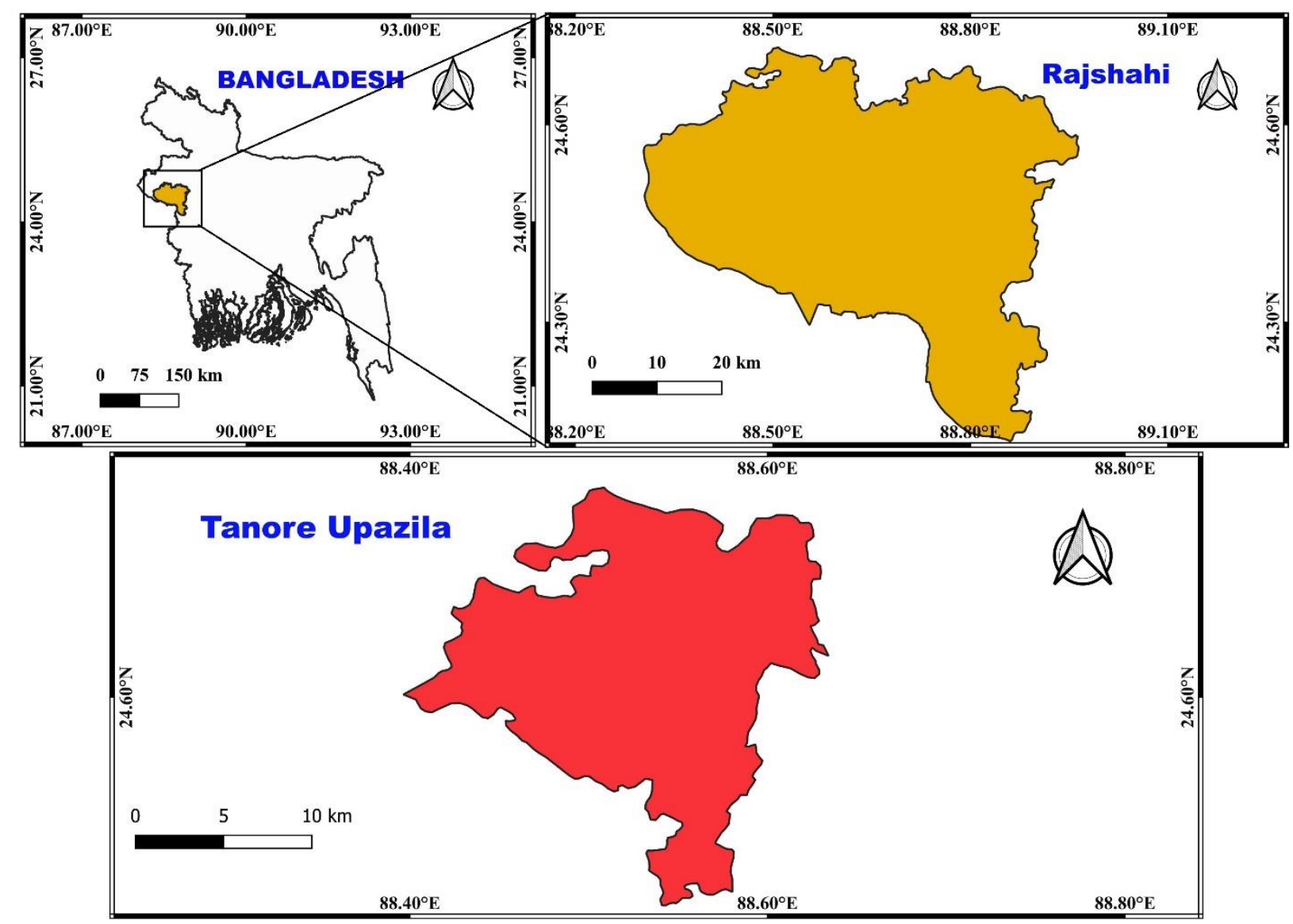

Figure 1. The map representing the Tanore upazila, which was considered for study sites.

Table 1. Experimental layout.

\begin{tabular}{llll}
\hline Treatment & Feeding frequency & Feeding time & Stocking density \\
\hline $\mathrm{T}_{1}$ & Twice & $\begin{array}{l}\text { Morning at } 8 \mathrm{am} \\
\text { Afternoon at } 5 \mathrm{pm}\end{array}$ & $74259 / \mathrm{ha}$ \\
\hline $\mathrm{T}_{2}$ & Thrice & $\begin{array}{l}\text { Morning at } 8 \mathrm{am} \\
\text { Noon at } 12.30 \mathrm{pm} \\
\text { Afternoon at } 5 \mathrm{pm}\end{array}$ & $74259 / \mathrm{ha}$ \\
\hline $\mathrm{T}_{3}$ & Forth & $\begin{array}{l}\text { Morning at } 8 \mathrm{am} \\
\text { Morning at } 11 \mathrm{am}\end{array}$ & $74259 / \mathrm{ha}$ \\
& & $\begin{array}{l}\text { Noon at } 2.30 \mathrm{pm} \\
\text { Afternoon at } 5 \mathrm{pm}\end{array}$ & \\
\hline
\end{tabular}




\subsection{Collection of experimental fish}

Satata Matsha Hatchery and Fishery, Tarakanda, Mymensingh, provided the pabda fry for this experiment. The fingerlings were transported to the study location in a plastic bag that was well aerated to ensure adequate aeration. All of the fish were from the same age group and had a mean weight of $0.51 \pm 0.01 \mathrm{~g}$ (on average) with the treatments T1, T2, and T3, which stood for T1, T2, and T3, respectively. Prior to the commencement of the trial, the Pabda (O. pabda) fingerlings in each pond were given a nutritional boost. Following that, the fish were introduced into the ponds in accordance with the experimental design.

\subsection{Pond preparation}

Aquatic weeds and all unwanted fish species were physically and chemically removed from the ponds, with the use of rotenone as a last resort. The rotenone was applied at a rate of 15-20 g per 6 feet and 1 decimal water, depending on the situation. Liming was carried out at a rate of $1.5 \mathrm{~kg} /$ decimal before to the application of fertilizer for seven days. Most of the pond preparation procedures were followed which was described by Biswas et al. (2018).

\subsection{Stocking}

The fingerlings were placed into a plastic bucket and released into the experimental pond once they had been properly acclimated to their new environment. The rate of fingerlings stocking per 74259/ha for each treatment was calculated. The fish were released at random into three separate ponds, each with a different treatment. Measurements were taken and recorded for the length and weight of about 5 percent of all fry in each pond. This information was used to estimate initial stocking biomass and to modify the first feeding frequency for fish.

\subsection{Post stocking management}

\subsubsection{Fertilization}

All the ponds were fertilized with organic fertilizer as a weekly basis, Urea: 100-120 gm/dec/week and TSP: 50$75 \mathrm{gm} / \mathrm{dec} /$ week was same for all treatments).

\subsubsection{Feeding management of fishes}

The fish were initially fed at a ratio of $20 \%$ of their body weight in the fingerling stage, in the early growing stage fed $10 \%$ feed and in the growing stage fish were fed $8 \%$ feed of their body weight (Table 2).

Table 2. Feeding management in pond setup.

\begin{tabular}{lll}
\hline Stage & Number of months & \% of feed (body weight) \\
\hline Fingerling & First & 20 \\
Early growing stage & Second & 10 \\
Growing stage & Rest & 8 \\
\hline
\end{tabular}

The provided fish feed contained $28 \%$ protein, which was written on the pack of the feed (C.P. Feed Ltd.). The proximate composition of feed components and experimental diets was determined using the procedures outlined in the Association of Official Analytical Chemists' Handbook of Analytical Methods (AOAC, 2016) by the company and the label were stacked on every bags of feed (Table 3 and 4).

Table 3. Composition of different feed ingredients used in experiment.

\begin{tabular}{ll}
\hline Ingredients & Amount (\%) \\
\hline Fish meal & 25 \\
Rice bran & 20 \\
Wheat bran & 18 \\
Mustard oil cake & 20 \\
Maize bran & 15 \\
Vitamin and mineral & 2 \\
Total amount & 100 \\
\hline
\end{tabular}


Table 4. Proximate composition of the feed used in the experiment.

\begin{tabular}{ll}
\hline Proximate composition $(\boldsymbol{\%})$ & Diet \\
\hline Moisture & 14 \\
Crude protein & 28 \\
Crude lipid & 9.6 \\
Crude fiber & 11.33 \\
Ash & 12.26 \\
NFE & 24.81 \\
\hline
\end{tabular}

* Nitrogen free extract (NFE) was calculated as 100- (moisture +crude protein+ crude lipid +ash + crude fiber)

\subsection{Water quality monitoring}

The temperature of the water was measured using a centigrade thermometer with a temperature range of $0^{\circ} \mathrm{C}$ to $120^{\circ} \mathrm{C}$. A Secchi disc with a diameter of $20 \mathrm{~cm}$ was used to measure the clarity of water in centimeters $(\mathrm{cm})$. The levels of soluble oxygen, alkalinity, and ammonia-nitrogen in the water were determined using a water quality test kit (HACK, FF2, USA). Hanna Pocket $\mathrm{pH}$ Meter was used to test the $\mathrm{pH}$ of the water (Model-HI98107). In the three settings, all of the water quality indicators were monitored on a month basis.

\subsection{Growth sampling of fish and harvest}

A seine net was used to collect samples of fish every month to evaluate their growth and overall health. At least ten percent of the fish from each pond were removed in order to evaluate growth patterns and modify feeding rates. Using a measuring scale and a digital electronic balance, researchers assessed the length and weight of the fish samples (OHAUS, MODEL no. HL-400). After 4 months, all of the fish were collected from each pond by collecting them repeatedly using a seine net. This was done in the month of July.

\subsection{Growth parameters}

For evaluating the performance of fishes under various treatments, a number of metrics (weight gain, length gain, specific growth rate, survival rate, FCR, and production of fishes) were employed to measure their progress.

\subsection{Analysis of experimental data}

\subsubsection{Mean weight gain}

Mean weight gain of fish was calculated by the following parameters,

Mean weight gain $(\mathrm{g})=$ Mean final weight- Mean initial weight

\subsubsection{Total weight gain}

The calculation of the mean weight gain with the number of fish is referred as total weight gain. It will be calculated as,

Total weight gain $=$ Mean weight gain $\times$ number of fish

\subsubsection{Percentage of weight gain:}

It is measured of the overall increased in mean body weight over a time period. It will be calculated as, Percentage weight gain $=\frac{\text { Mean final fish weight-Mean initial fish weight }}{\text { Mean initial weight }} \times 100$

\subsubsection{Survival rate $(\%)$}

Survival rate of fish was calculated by the following formula,

Survival rate $(\%)=($ No. of fish harvested/ No. of fish stocked $) \times 100$

\subsubsection{Specific growth rate (SGR)}

Specific growth rate $\left(\mathrm{SGR}, \mathrm{bwd}^{-1}\right)$ will be calculated as,

Specific Growth Rate (SGR, \% per day) $=\frac{\log _{\mathrm{e}} \mathrm{W}_{2}-\log _{\mathrm{e}} \mathrm{W}_{1}}{\mathrm{~T}_{2}-\mathrm{T}_{1}} \times 100$

Where,

$\mathrm{W} 1=$ Initial live body weight $(\mathrm{g})$ at time $\mathrm{T}_{1}$ (day)

$\mathrm{W} 2=$ Final live body weight $(\mathrm{g})$ at time $\mathrm{T}_{2}$ (day)

$\mathrm{T}_{2-} \mathrm{T}_{1}=$ Duration of the experiment (day) 


\subsubsection{Production of fishes}

Production of fishes was calculated based on average final weight of the harvested fishes and was expressed $\mathrm{kg} / \mathrm{ha}$. The formula is as follows,

Production $=$ No. of fish harvested $\times$ final weight gain of fishes.

\subsubsection{Feed conversion ratio}

Food conversion ratio (FCR) was also calculated to evaluate the feeding efficiency of fishes under different treatment as follows,

$\mathrm{FCR}=$ Feed fed/Total body weight gain

\subsubsection{Economics analysis}

To investigate the economics of monoculture under various treatment scenarios, a cost-benefit analysis approach was used in the current research. In order to calculate the overall cost (Tk/ha/ 4 months), information on both fixed and variable expenses was collected. It was estimated that the net profit was equal to $\mathrm{Tk} / \mathrm{ha} / 4$ months after subtracting the entire return from the whole expenditure.

CBR was calculated as follows: $\mathrm{CBR}=$ Net benefit/total cost.

\subsection{Statistical analysis}

One-way analysis of variance (ANOVA) of water quality parameters and other physiological parameters of fishes were performed using the SPSS (Statistical Product and Service Solutions; SPSS 28 - 2021). Significance was assigned at the $0.05 \%$ level. The DMR (Duncan's New Multiple Range Test) was used to compare the mean values in order to determine whether or not there was a statistically significant difference. The map of the study area was created with the help of the QGIS programme (QGIS Development Team, 2019).

\section{Results}

\subsection{Water quality parameters}

The average water temperature significantly ranged between $27.29 \pm 2.16\left(\mathrm{~T}_{1}\right)$ and $27.13 \pm 2.10{ }^{\circ} \mathrm{C}\left(\mathrm{T}_{3}\right)$, while the water transparency ranged between $31.91 \pm 1.58$ and $29.96 \pm 1.84 \mathrm{~cm}$ among three treatments. The average dissolved oxygen ranged between $5.35 \pm 0.11$ and $5.47 \pm 0.07 \mathrm{mg} / \mathrm{l}$ among three setup. The average value of $\mathrm{pH}$ ranged between $7.62 \pm 0.14$ and $7.70 \pm 0.19$ among culture setup; while the alkalinity ranged between $109.86 \pm 9.08$ and $114.44 \pm 9.27 \mathrm{mg} / \mathrm{l}$ among three setup. On the other hand $\mathrm{NH}_{3}-\mathrm{N}$ was ranged between $0.13 \pm 0.005$ and $0.14 \pm 0.01 \mathrm{mg} / \mathrm{l}$ among three treatments (Table 5).

Table 5. Average values of physico-chemical characteristics under different treatment.

\begin{tabular}{llll}
\hline \multicolumn{1}{c}{ Treatments } & $\mathbf{T}_{\mathbf{1}}$ & $\mathbf{T}_{\mathbf{2}}$ & $\mathbf{T}_{\mathbf{3}}$ \\
Characteristics & & & \\
\hline Water temperature $\left({ }^{\mathbf{0}} \mathbf{C}\right)$ & $27.29 \pm 2.16^{\mathrm{a}}$ & $27.26 \pm 2.04^{\mathrm{ab}}$ & $27.13 \pm 2.10^{\mathrm{ab}}$ \\
Transparency $(\mathbf{c m})$ & $29.96 \pm 1.84^{\mathrm{c}}$ & $31.91 \pm 1.58^{\mathrm{a}}$ & $31.62 \pm 1.08^{\mathrm{b}}$ \\
$\mathbf{D O}(\mathbf{m g} / \mathbf{l})$ & $5.35 \pm 0.11^{\mathrm{b}}$ & $5.56 \pm 0.14^{\mathrm{a}}$ & $5.47 \pm 0.07^{\mathrm{ab}}$ \\
$\mathbf{p H}$ & $7.69 \pm 0.12^{\mathrm{a}}$ & $7.62 \pm 0.14^{\mathrm{b}}$ & $7.70 \pm 0.19^{\mathrm{a}}$ \\
Alkalinity (mg/l) & $109.86 \pm 9.08^{\mathrm{b}}$ & $111.25 \pm 8.90^{\mathrm{b}}$ & $114.44 \pm 9.27^{\mathrm{a}}$ \\
$\mathbf{N H}_{\mathbf{3}}-\mathbf{N}(\mathbf{m g} / \mathbf{l})$ & $0.14 \pm 0.01^{\mathrm{a}}$ & $0.13 \pm 0.005^{\mathrm{ab}}$ & $0.13 \pm 0.02^{\mathrm{ab}}$ \\
\hline
\end{tabular}

Values in a row bearing common letter (a) do not differ significantly different $(\mathrm{p}<0.05)$ values are given \pm standard deviation.

\subsection{Growth parameters}

\subsubsection{Specific Growth Rate (SGR)}

The recorded mean specific growth rate of treatments $\mathrm{T}_{1}, \mathrm{~T}_{2}$ and $\mathrm{T}_{3}$ were $3.62 \pm 0.01,3.94 \pm 0.01$ and $3.60 \pm 0.01$ respectively, which were significantly $(\mathrm{p}<0.05)$ different among the treatments. The highest SGR value 3.94 \pm 0.01 was recorded treatment $T_{2}$ while the lowest $3.60 \pm 0.01$ was obtained in $T_{3}$ (Table 5). The other growth parameters such as mean initial weight $(\mathrm{g})$, final weight $(\mathrm{g})$, weight gain $(\mathrm{g})$, initial length $(\mathrm{cm})$, final length $(\mathrm{cm})$, and length gain $(\mathrm{cm})$ is presented in Table 6 . 


\subsubsection{Survival rate $(\%)$}

The survival ranged between $90.43 \pm 0.01$ to $96.77 \pm 0.01$ (Table 6), while they were significantly difference $(\mathrm{p}<0.05)$ among the treatments. The highest $(96.77 \pm 0.01)$ survival rate was obtained in the treatment $\mathrm{T}_{2}$ and the lowest $(90.43 \pm 0.01)$ survival rate was obtained in the treatment $\mathrm{T}_{1}$ (Table 6$)$.

\subsubsection{Food conversion ratio (FCR)}

The food conversion ratio (FCR) values among the treatments were ranged between $1.90 \pm .01$ to $2.87 \pm 0.01$ (Table 6). The lowest FCR $(1.90 \pm 0.01)$ was obtained with treatment $\mathrm{T}_{2}$ while the highest FCR was obtained with $\mathrm{T}_{3}$.

\subsubsection{Fish production (kg/ha)}

The production of $O$. pabda ranged between $2677.95 \pm 0.01$ to $4049.1 \pm 0.100 \mathrm{~kg} / \mathrm{ha} / 120$ days (Table 5) in different treatments. Treatment $T_{2}$ resulted significantly $(\mathrm{p}<0.05)$ highest $(4049.1 \pm 0.100)$ production compared to treatment $\mathrm{T}_{1}$ and treatment $\mathrm{T}_{3}$ (Table 6).

Table 6. Growth and production performance of $O$. pabda under different treatments during the study period.

\begin{tabular}{llll}
\hline \multicolumn{1}{c}{ Treatments } & $\mathbf{T}_{\mathbf{1}}$ & $\mathbf{T}_{\mathbf{2}}$ & $\mathbf{T}_{\mathbf{3}}$ \\
Characteristics & & & \\
\hline Mean initial weight $(\mathrm{g})$ & $0.520 \pm 0.005^{\mathrm{a}}$ & $0.501 \pm 0.007^{\mathrm{a}}$ & $0.511 \pm 0.01^{\mathrm{a}}$ \\
Mean final weight $(\mathrm{g})$ & $40.67 \pm 1.06^{\mathrm{b}}$ & $56.36 \pm 1.25^{\mathrm{a}}$ & $38.23 \pm 1.01^{\mathrm{c}}$ \\
Mean weight gain $(\mathrm{g})$ & $40.15 \pm 0.75^{\mathrm{b}}$ & $55.86 \pm 1.46^{\mathrm{a}}$ & $37.72 \pm 0.48^{\mathrm{c}}$ \\
Mean initial length $(\mathrm{cm})$ & $4.36 \pm 0.25^{\mathrm{a}}$ & $4.35 \pm 0.25^{\mathrm{a}}$ & $4.34 \pm 0.25^{\mathrm{a}}$ \\
Mean final length $(\mathrm{cm})$ & $18.23 \pm 0.04^{\mathrm{b}}$ & $22.36 \pm 0.05^{\mathrm{a}}$ & $17.12 \pm 0.09^{\mathrm{b}}$ \\
Mean length gain $(\mathrm{cm})$ & $13.87 \pm 0.79^{\mathrm{b}}$ & $18.01 \pm 0.85^{\mathrm{a}}$ & $12.78 \pm 0.63^{\mathrm{b}}$ \\
SGR (\%bwd $\left.{ }^{-1}\right)$ & $3.62 \pm 0.22^{\mathrm{b}}$ & $3.94 \pm 0.22^{\mathrm{a}}$ & $3.60 \pm 0.22^{\mathrm{b}}$ \\
Survival rate (\%) & $90.43 \pm 0.01^{\mathrm{c}}$ & $96.77 \pm 0.01^{\mathrm{a}}$ & $94.32 \pm 0.01^{\mathrm{b}}$ \\
FCR & $2.82 \pm 0.01^{\mathrm{b}}$ & $1.90 \pm 0.01^{\mathrm{c}}$ & $2.87 \pm 0.01^{\mathrm{a}}$ \\
Production(kg/dec) & $11.03 \pm 0.01^{\mathrm{b}}$ & $16.36 \pm 0.01^{\mathrm{a}}$ & $10.82 \pm 0.005^{\mathrm{b}}$ \\
Production $(\mathrm{kg} / \mathrm{ha})$ & $2729.92 \pm 0.01^{\mathrm{b}}$ & $4049.1 \pm 0.1^{\mathrm{a}}$ & $2677.95 \pm 0.01^{\mathrm{b}}$
\end{tabular}

Figures in a row bearing common letter (a) do not differ significantly different $(\mathrm{p}<0.05)$ values are given \pm standard deviation

\subsection{Economic analysis}

The total cost of inputs and profit per decimal were significantly different $(\mathrm{p}<0.05)$ among the treatments. The cost of input was similar in $T_{1}, T_{2}$ and $T_{3}$. The net profit was highest in $T_{2}$ and lowest in treatment $T_{3}$, which was significantly different among the treatments. The selling price of marketable fish in Rajshahi region was 400 $\mathrm{BDT} / \mathrm{kg}$. Cost and benefit ratio were calculated 1: 0.30, 1: 0.93 and 1: 0.27 among $\mathrm{T}_{1}, \mathrm{~T}_{2}$ and $\mathrm{T}_{3}$ respectively (Table 7).

Table 7. Input cost and profit from $O$. pabda for 120 days in ponds of three different treatments.

\begin{tabular}{llll}
\hline \multicolumn{1}{c}{ Treatments } & $\mathbf{T}_{\mathbf{1}}$ & $\mathbf{T}_{\mathbf{2}}$ & $\mathbf{T}_{\mathbf{3}}$ \\
Component & & & \\
\hline Pond preparation (BDT/ha) & 86625.0 & 86625.0 & 86625.0 \\
Cost of fry (BDT /ha) & 89100.0 & 89100.0 & 89100.0 \\
Feed cost (BDT /ha) & 520987.0 & 520987.0 & 520987.0 \\
Cost of fertilization(BDT /ha) & 66825.0 & 66825.0 & 66825.0 \\
Operational cost(BDT /ha) & 74250.0 & 74250.0 & 74250.0 \\
Total cost (BDT /ha) & 837787.0 & 837787.0 & 837787.0 \\
Total income(BDT /dec) & 1091970.0 & 1619640.0 & 1071180.0 \\
Net profit(BDT /dec) & 254182.0 & 781852.0 & 233392.0 \\
Cost benefit ratio (CBR) & 0.30 & 0.93 & 0.27 \\
\hline
\end{tabular}

\footnotetext{
*Leasing cost is not included.
} 


\section{Discussion}

The primary goal of aquaculture is to increase the production of aquatic biomass in order to meet the growing needs of society on a daily basis. Aquaculture feed is the most pressing issue facing the industry. Fishermen's feeds are very expensive, and the anticipated conversion efficiency is not always achieved. Boosting the benefit level of fish farmers may be accomplished by lowering feed costs or by increasing output via the use of knowledge of feeding regimens (Dauda et al., 2019; Naylor et al., 2021; White, 2013).

Under this research, feed was utilized for the farming of $O$. pabda fingerlings in field conditions, with fish being fed at various stages of their growth throughout the process. Fish were fed according to their life stage, which was divided into three stages: fingerling stage, early growth stage, and growing stage. The fish were given $20 \%$ of their body weight in feed during the fingerling stage, 10\% during the early developing stage, and $8 \%$ throughout the growing stage.

Physico-chemical characteristics as well as growth parameters were measured on a monthly basis during the research period. Feeding frequencies in the therapy for (T1) were twice daily, whereas treatment (T2) feed was provided three times daily, and treatment (T3) feed was provided four times daily in the treatment. During the experimental period, water quality measurements as well as growth metrics were measured on a monthly basis as well.

Environmental parameters play an important part in maintaining a healthy habitat for fish to live in, whereas the growth, feed efficiency, and feed intake of fish are typically controlled by a small number of environmental variables in most cases (Komal et al., 2021; Soler et al., 2021; Stavrescu-Bedivan et al., 2016). It also plays a significant role in producing live food organism which is preferred by most of the fish. The criteria governing water quality should be properly monitored and maintained; otherwise, they may be harmful to the health of the fish. Poor water quality may slow the development rate of fish and even cause them to get disease, resulting in a reduction in the amount of fish that can be harvested (Bhateria and Jain, 2016; Makori et al., 2017).

Temperature has an effect on the growth, reproduction, and other biological processes of fish (Islam et al., 2019). Water temperature of the pond water was recorded every month during the experimental period, and recorded water temperature more or less similar in different treatments. The average water temperature was recorded as $27.14 \pm 0.01-27.23 \pm 0.01^{\circ} \mathrm{C}$ in the treatments. The minimum value was recorded with treatment $\mathrm{T}_{3}$ in the first month. The maximum value was recorded with the $\mathrm{T}_{1}$ in the fourth months. Samad et al. (2021) suggested the temperature in the culture setup were $28.50^{\circ} \mathrm{C}$ among the treatments while Nahar et al. (2021) found temperature fluctuated between 25.01 and $26.13^{\circ} \mathrm{C}$; on the other hand Shajib et al. (2018) showed the temperature could be ranged between 25.25 and $27.50{ }^{\circ} \mathrm{C}$ in hapa set up was found to be suitable for fish growth, as better weight gain and lower FCR were recorded during this period.

The amount of dissolved oxygen in water is another key water quality characteristic that fish rely on to survive (Makori et al., 2017). It is important to note that if dissolved oxygen deficiency is discovered in the pond water, the fish will begin to grip, and aeration should be supplied quickly; else, serious fish death may result (Boyd $e t$ al., 2018).

The mean value of water content in the treatments $T_{1}, T_{2}$ and $T_{3}$ were $5.31 \pm 0.01,5.75 \pm 0.01$, and 5.47 \pm 0.01 .this is respectively similar to the recommended value. In the treatment $T_{2}$ which provide best benefit that contain $5.75 \pm 0.01 \mathrm{mg} / \mathrm{l}$ oxygen and it provided supplementary feed thrice time daily. In the winter month the oxygen content of the aquaculture pond were less than in the summer months. Samad et al. (2021) suggested the dissolved oxygen (DO) level in cage culture might be fluctuated between $5.48 \pm 0.02$ and $5.72 \pm 0.11 \mathrm{mg} / \mathrm{l}$; while the average DO level ranged between $5.02 \pm 0.45$ and $5.27 \pm 0.60 \mathrm{mg} / \mathrm{l}$ in small catfish aquaculture pond reported by Nahar et al. (2021). On the other hand a poly culture setup suggested that the DO might fluctuated between $5.29 \pm 0.27$ and $5.93 \pm 0.66 \mathrm{mg} / \mathrm{l}$ (Zafar et al., 2017).

The mean $\mathrm{pH}$ range was found between $7.54 \pm 0.01$ and $7.63 \pm 0.01$ during the study period, In which the acceptable range required for fish culture 6.5-9.0 (Boyd, 1990). The growth rate, metabolic rate, and other physiological functions of fish are all reduced when the $\mathrm{pH}$ is too acidic (Chabot et al., 2016; Mota et al., 2018). Study of Mondal et al. (2020a) in a confined small indigenous species production system found $\mathrm{pH}$ ranged between 7.92 and 8.02; while the study of Samad and Imteazzaman (2019) revealed the pH ranged between $7.8 \pm 0.32$ and $8.25 \pm 0.44$, which also support the present findings.

Alkalinity does not directly contribute to the development of aquatic biotic organisms. Essential nutrients are found in greater abundance in alkaline waters than in acidic waters, and this is the most significant explanation for the increased biological productivity seen in alkaline waters compared to acidic waters (Marimuthu et al., 2019; Wilkie and Wood, 1996). Alkalinity (mg/l) values were vary from $98.76 \pm 1.01 \mathrm{mg} / \mathrm{l}$ to $120.90 \pm .23 \mathrm{mg} / \mathrm{l}$. The minimum value was recorded with the treatment $\mathrm{T}_{2}$ in the second month. The maximum value was recorded with the treatment $T_{3}$ in the fourth month. Significant difference was found among the treatments at different 
months. In the present study the mean alkalinity of different treatments were $112.82 \pm .01,111.25 \pm .01$ and $114.41 \pm 0.01$ which were in acceptable range.

$\mathrm{NH}_{3}-\mathrm{N}(\mathrm{mg} / \mathrm{l})$ values were found to be ranged from $0.11 \pm 0.01 \mathrm{mg} / \mathrm{l}$ to $0.16 \pm 0.01 \mathrm{mg} / \mathrm{l}$. The minimum value was recorded with the treatment $T_{3}$ in the first month. The maximum value was recorded with the treatment $T_{1}$ in the $4^{\text {th }}$ month. Significant difference was found among the treatments at different months. The ammonia content of the three treatments $\mathrm{T}_{1}, \mathrm{~T}_{2}$ and $\mathrm{T}_{3}$ were $0.15 \pm 0.01,0.13 \pm 0.01$ and $0.12 \pm 0.01$; while the findings of Samad et al. (2021) Samad and Imteazzaman (2019) were almost similar with the present study.

During the study the growth performance of pabda $(O$. pabda) varied in different feeding frequencies. Observation on the growth rate of fishes in various treatments showed that in 120 days rearing period, the average weight gain $(40.67 \pm 0.01)$ was attained in treatments $T_{1}$ in regular feeding frequency two times per day. In treatment $T_{2}$ the average weight gain was $(56.36 \pm 0.01)$ which regular feeding frequency was three times per day. In the treatments $T_{3}$ the average weight gain was $(38.23 \pm 0.01)$ that was provide the regular feeding frequency was four times per day.

Noeske-Hallin et al. (1985) reported that the channel catfish grew more slowly when fed to station once per day than when fed 2 or 4 times. Studies of some fish species have shown that the highest weight gain was obtained $(\mathrm{p}<0.05)$ by feeding the fish (three times daily), providing more feed (Başçıar and Çakmak, 2007). In the treatments the highest weight gain was attained in the treatment $T_{2}$ and the lowest weight gain was attain in the treatment $T_{3}$. In the treatment $T_{2}$ the feed was applied utilized properly. But in treatment $T_{1}$ the feed applied was excess than needed as a result the excess feed effect on the water quality that shortened the growth performance of the fish in the treatment $\mathrm{T}_{1}$.

The values of specific growth rate of pabda $(O . p a b d a)$ were observed as $3.62 \pm 0.01,3.94 \pm 0.01$ and $3.60 \pm 0.01$ in treatments $\mathrm{T}_{1}, \mathrm{~T}_{2}$, and $\mathrm{T}_{3}$ respectively. There were significantly differences $(\mathrm{p} \leq 0.01)$ among different treatments. SGR progressively increased with the increase in feeding frequency but in $T_{1}$ the excessive feeding decrease the growth rate. The significantly highest Specific growth rate (SGR) in $\mathrm{T}_{2}$, might be due to the fact that the fish have utilized effectively the supplied feed taking small amount at a rate of 3 times in a day. Samad et al. (2005) found that the SGR is higher than the present findings. Similar investigation were made by Debnath et al. (2016) on Ompok bimaculatus fingerling during culture. Malla and Banik (2015)reported that SGR of Ompak bimaculatus was $4.79 \pm 0.58$ to $3.46 \pm 0.31$ that is similar with the present study. Similar phenomena were also observed in other fish species, for instance, tilapia (Haq et al., 2017).

The highest survivability was recorded in treatment $\mathrm{T}_{2}(96.77 \pm 0.01)$ and the lowest survivability was in treatment $\mathrm{T}_{1}(90.43 \pm 0.01)$. There was significant difference $((\mathrm{p} \leq 0.01)$ among the different treatment. A similar survival rate was observed by who recorded survival rate ranged from 94 to $96 \%$. Similar result were obtained by Rahman et al. (2012) for the fingerlings of Channa striatus. While the study of Slembrouck et al. (2009) and Sharma and Chakrabarti (1999) reported enhanced growth and survival of carp larvae in a recirculation system and such possibility for high density larvae rearing of this catfish needs to be explored.

The feed utilization was calculated in terms of food conversion ratio (FCR). In the present study, the values of food conversion ratio (FCR) were varied between $1.90 \pm 0.01$ and $2.87 \pm 0.01$. A low FCR value is an indicator of better food utilization efficiency of formulated diet. The lowest i.e. the best FCR (1.90 \pm 0.01$)$ was observed in treatment $T_{2}$ with 3 times feeding frequency and the highest i.e. the worst FCR value $(2.87 \pm 0.01)$ was recorded in treatment $\mathrm{T}_{3}$ with the feeding frequency of four times a day. Ndome et al. (2011) reported that channel catfish fed at frequencies of once daily had the highest feed conversion ratios 2.35 with low weight gain and the fed twice and thrice daily had the lowest FCR 1.95 and 1.91. It is comparatively similar to the present study.

A recent study of Samad et al. (2021) suggested that another small sized catfish FCR ranged between 2.20 and 2.97 which is relevant with the present study. $O$. pabda is known to be a predominantly omnivorous fish, consuming phytoplankton, zooplankton and decaying suspended organic matter. A large portion of the designed feed may have been effectively used by the fish, and the feed that was utilized contributed to the creation of natural food by releasing nutrients via decomposition. In ponds where feeding was performed, uneaten feed and metabolic waste created nutrient enrichment, which increased plankton production by increasing the availability of nutrient.

The highest production was observed to be $4049.1 \pm 0.100 \mathrm{~kg} / \mathrm{ha} / 120$ days in treatment $\mathrm{T}_{2}$ and the lowest production was observed to be $2677.95 \pm 0.01 \mathrm{~kg} / \mathrm{ha} / 120$ days in treatment $\mathrm{T}_{3}$. The maximum fish production was obtained in treatment $T_{2}$ under the three time feeding frequency and production was found to be decreased significantly with the decrease in feeding frequencies and with the increase in feeding frequencies. Samad et al. (2014) obtained net production $2595.2 \mathrm{~kg} / \mathrm{ha}$ to $3389.4 \mathrm{~kg} / \mathrm{ha}$ for 6 months of Clarias batrachus that is lower than the present study. Samad et al. (2017b) was found net production of Heteropneustes fossilis $2249.98 \mathrm{~kg} / \mathrm{ha}$ during the culture period of three months that is lower than the present study because of short time culture 
period. The lowest fish production in the present study was $2677.95 \pm 0.01 \mathrm{~kg} / \mathrm{ha} / 120$ days was observed in treatment $\mathrm{T}_{3}$ which might be due to insufficient feed supply and decreased feed efficiency. Considering the overall growth performance, survival rate, specific growth rate (SGR), FCR value and production, the best result was obtained in treatment $t_{2}$ with three times feeding frequencies in a day.

The cost of production was based on the Rajshahi wholesale market price of the input used of the year 2018. Cost of fry was $0.120 \mathrm{BDT} /$ piece. Feed cost depends on the stage of fish, on the fingerling stage the fingerling was fed starter feed which was $90 \mathrm{TK} / \mathrm{kg}$. In the early growing stage the fish were fed which was $75 \mathrm{TK} / \mathrm{kg}$. The growing stage the fish were fed was $50 \mathrm{TK} / \mathrm{kg}$. The cost of input was similar in $\mathrm{T}_{1}, \mathrm{~T}_{2}$ and $\mathrm{T}_{3}$. Total cost for

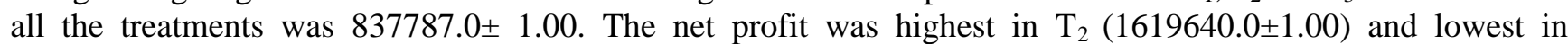
treatment T3 (1071180.0 \pm 1.00$)$, which was significantly different among the treatments. Cost and benefit ratio were calculated 1: .30, 1:.93 and 1:.27 among $\mathrm{T}_{1}, \mathrm{~T}_{2}$ and $\mathrm{T}_{3}$ respectively. The present findings were coincided with the findings of Samad et al. (2016) in Labeo bata nursery pond. The present findings are somewhat lower than the findings were obtained from Samad et al. (2014) who studied that the CBR was highest in $\mathrm{T}_{3}(1: 1.24)$ and the lowest was found in $\mathrm{T}_{1}(1: 0.056)$ for Clarias batractus in ponds. Similar economics were assessed by Rahman et al. (2017) elsewhere in Bangladesh.

\section{Conclusions}

The farmer may optimize their advantage by feeding $O$. pabda three times a day instead of the usual twice or four times. The treatment $T_{2}$, in which provides additional feed thrice day, showed good growth and output. It is concluded that one stage raising of $O$. pabda with proper feeding frequency would provide greater yields of pabda fish in a short time. The study will make farmers aware of the benefits of feeding three times daily.

\section{Conflict of interest}

None to declare.

\section{Authors' contribution}

Conceptualization and execution of study: Md. Ashraful Islam and Md. Abdus Samad; methods: Md. Abdus Samad; data collection: Md. Ashraful Islam and Md. Abdus Samad; statistics and presentation: Md. Ashraful Islam and Abdulla-Al-Asif; Map preparation: Abdulla-Al-Asif; writing, original-draft preparation: Md. Ashraful Islam, Md. Abdus Samad and Abdulla-Al-Asif; writing, review and editing: Dipankar Paul, Abdulla-Al-Asif and Amir Hossain. All authors have read and agreed to the published version of the manuscript.

\section{References}

Aaqillah-Amr MA, A Hidir, MN Azra, AR Ahmad-Ideris, MH Abualreesh, MN Noordiyana and M Ikhwanuddin, 2021. Use of pelleted diets in commercially farmed decapods during juvenile stages: A review. Animals, 11: 1-31.

Aderolu AZ, BM Seriki, L Apatira and CU Ajaegbo, 2010. Effects of feeding frequency on growth, feed efficiency and economic viability of rearing African catfish (Clarias gariepinus, Burchell 1822 ) fingerlings and juveniles. African J. Food Sci., 4: 286-290.

Adnan K, S Sarker, K Akhi and M Rahman, 2016. An economic analysis of year round Pangus production and social impact in some selected areas of Mymensingh district in Bangladesh. Asian J. Agric. Extension, Econ. Sociol., 10: 1-11.

Alam J, S Andriyono, A Hossain, ATM Eunus and HW Kim, 2019. The complete mitochondrial genome of a Pabdah catfish, Ompok pabda (Hamilton, 1822). Mitochondrial DNA Part B Resour., 4: 507-508.

Ali MM, A Al-Asif, MAI Shabuj, S Vaumik, MA Zafar, BMN Sharif, 2016. Status of polyculture Pangasius hypophthalmus with carps in Jhikargacha Upazila of Jessore district , Bangladesh. Int. J. Fish. Aquat. Stud., 4: 423-430.

AOAC, 2016. Official methods of analysis. AOAC International, Rockville.

Apper-Bossard, E., Feneuil, A., Wagner, A., Respondek, F., 2013. Use of vital wheat gluten in aquaculture feeds. Aquat. Biosyst. 9: 21.

Asadujjaman M, MA Wahab, MK Fatema, MB Hossain and AKMS Azam, 2013. Effects of stocking density on growth performance and production of mola, Amblypharyngodon mola. Sains Malaysiana, 42: 1231-1235.

Başçınar N and E Çakmak, 2007. The effect of feeding frequency on growth performance and feed conversion rate of black sea trout (Salmo trutta labrax Pallas, 1811). Turkish J. Fish., 17: 13-17.

Bhateria R and D Jain, 2016. Water quality assessment of lake water: a review. Sustain. Water Resour. Manag., 
2: $161-173$.

Bhattacharjee P and P Pal, 2020. Study on length weight relationship and feeding habits of a threaten fish Ompok pabda from Tripura, India. J. Entomol. Zool. Stud., 8: 1971-1975.

Billah MM, MK Uddin, MYA Samad, MZB Hassan, MP Anwar, I Talukder, M Shahjahan and ANA Haque, 2020. Impact of feeding schedule on the growth performances of tilapia, common carp, and rice yield in an integrated rice-fish farming system. Sustain., 12: 1-13.

Biswas C, MMM Hossain, A Al-Asif, B Sarker, MM Billah and MA Ali, 2018. Culture strategies, diseases and their mitigations in mono-sex Nile tilapia farming in Jessore sadar region, Bangladesh. Asian-Australasian J. Biosci. Biotechnol., 3: 190-200.

Bogard JR, AL Hother, M Saha, S Bose, H Kabir, Marks GC and SH Thilsted, 2015a. Inclusion of small indigenous fish improves nutritional quality during the first 1000 days. Food Nutr. Bull., 36: 276-289.

Bogard JR, SH Thilsted, GC Marks, MA Wahab, MAR Hossain, J Jakobsen and J Stangoulis, 2015b. Nutrient composition of important fish species in Bangladesh and potential contribution to recommended nutrient intakes. J. Food Compos. Anal., 42: 120-133.

Boyd CE, 1990. Water quality in ponds for aquaculture. Alabama Agriculture Experiment Station, Auburn University, Alabama, USA.

Boyd CE, LR D'Abramo, BD Glencross, DC Huyben, LM Juarez, GS Lockwood, AA McNevin, AGJ Tacon, F Teletchea, JR Tomasso, CS Tucker and WC Valenti, 2020. Achieving sustainable aquaculture: Historical and current perspectives and future needs and challenges. J. World Aquac. Soc., 51: 578-633.

Boyd CE, EL Torrans and CS Tucker, 2018. Dissolved oxygen and aeration in Ictalurid catfish aquaculture. J. World Aquac. Soc., 49: 7-70.

Byrd KA, SH Thilsted and KJ Fiorella, 2021. Fish nutrient composition: A review of global data from poorly assessed inland and marine species. Public Health Nutr., 24: 476-486.

Chabot D, JF Steffensen and AP Farrell, 2016. The determination of standard metabolic rate in fishes. J. Fish Biol., 88: 81-121.

Chaklader R, M Abu, B Siddik, A Hanif, A Nahar, S Mahmud and M Piria, 2016. Morphometric and meristic variation of endangered pabda catfish, Ompok pabda (Hamilton-Buchanan, 1822) from Southern coastal waters of Bangladesh. Pak. J. Zool., 48: 681-687.

Chakraborty BK, ZA Mirza and A Chakraborty, 2010. Reproductive cycle of the endangered Pabda, Ompok pabda (Hamilton-Bouchanan, 1822) in Bangladesh. Asian Fish. Sci., 23: 301-320.

Cho SH, YS Lim, JH Lee, JK Lee, S Park and SM Lee, 2003. Effects of feeding rate and feeding frequency on survival, growth, and body composition of ayu post-larvae Plecoglossus altivelis. J. World Aquac. Soc., 34: 85-91.

Chowdhury G, MS Hossain, T Dey, S Akhtar, MA Jinia, B Das, MJ Islam and MM Iqbal, 2020. Effects of dietary probiotics on the growth, blood chemistry and stress response of pabda catfish (Ompok pabda) juveniles. AACL Bioflux, 13: 1595-1605.

Dauda AB, A Ajadi, AS Tola-Fabunmi and AO Akinwole, 2019. Waste production in aquaculture: Sources, components and managements in different culture systems. Aquac. Fish., 4: 81-88.

Debnath C, K Dube, N Saharan, VK Tiwari, M Datta, L Sahoo, GS Yadav and P Das, 2016. Growth and production of endangered Indian butter catfish, Ompok bimaculatus (Bloch) at different stocking densities in earthen ponds. Aquac. Res., 47: 3265-3275.

Dudgeon D, 2010. Threats to freshwater biodiversity globally and in the Indo-Burma Biodiversity Hotspot, in: Biodiversity. IUCN, pp. 1-28.

Eriegha OJ and PA Ekokotu, 2019. Factors affecting feed intake in cultured fish species: A review. Anim. Res. Int., 14: $2697-2709$.

Galib SM, MA Samad, MA Hossain, ABM Mohsin and SMM Haque, 2010. Small indigenous species of fishes (SIS) in Chalan Beel With reference to their harvesting and marketing system. Bangladesh J. Progress. Sci. Technol., 8: 251-254.

Gupta S, 2018. A review on feeding and reproductive biology of Ompok pabda with an emphasis on its conservation. J. Aquac. Res. Dev., 09: 1000525.

Haq ME, M Rahman, A Hossain, A Al-Asif, H Rahman, P Chwakravorty, A Satter and MS Islam, 2017. Comparative growth performance between monosex and natural XY male tilapia in Noakhali region, Bangladesh. Asian J. Med. Biol. Res., 3: 391-397.

Hasan MA, MA Wahab, MA Khateque, MT Alam, MS Alam and MA Samad, 2002. Carp polyculture in ponds with three small indigenous fish species Amblypharyngodon mola, Chela cachius and Puntius sophore. Progress. Agric., 13: 117-126. 
Hernandez LH and RW Hardy, 2020. Vitamin A functions and requirements in fish. Aquac. Res., 51: 30613071.

Hossain M, K Afsana and A Azad Shah, 1999. Nutritional value of some small indigenous fish species (SIS) of Bangladesh. Bangladesh J. Fish Res., 3: 77-85.

Hossain M, F Shikha and T Chakrabarty, 2019. Studies on the culture condition of Pangus (Pangasius hypophthalmus) at different farms in Trishal Upazila. J. Environ. Sci. Nat. Resour., 11: 97-107.

Hossain MA, HR Dipu and MR Haque, 2019. Aquaculture practice and production performance of pabda Ompok pabda (Hamilton, 1822) in Northern region of Bangladesh. Int. J. Fish. Aquat. Stud., 7: 171-175.

Hossain MY, 2010. Length-weight, length-length relationships and condition factors of three Schibid catfishes from the Padma River, Northwestern Bangladesh. Asian Fish. Sci., 23: 329-339.

Hossain MY, MA Hossen, K Yahya, MM Islam, MA Islam, KKU Ahmed and M Begum, 2015. Threatened fishes of the world: Ompok pabda (Hamilton, 1822) (Siluriformes: Siluridae). Ribar. Croat. J. Fish., 73: 183185.

Islam MA, MH Uddin, MJ Uddin and M Shahjahan, 2019. Temperature changes influenced the growth performance and physiological functions of Thai pangas Pangasianodon hypophthalmus. Aquac. Reports, 13: 100179.

IUCN Bangladesh, 2015. Red List of Bangladesh Volume 5: Freshwater Fishes. International Union for Conservation of Nature, Bangladesh Country Office, Dhaka, Bangladesh. pp. 360.

Kawarazuka N and C Béné, 2011. The potential role of small fish species in improving micronutrient deficiencies in developing countries: Building evidence. Public Health Nutr., 14: 1927-1938.

Klinger D and R Naylor, 2012. Searching for solutions in aquaculture: Charting a sustainable course. Annu. Rev. Environ. Resour., 37: 247-276.

Kohinoor AHM, MM Rahman, HM Moniruzzaman and SC Chakraborty, 2014. Production performance of pabda (Ompok pabda) and gulsha (Mystus cavasius) with GIFT strain (Oreochromis niloticus) in on-farm management system. Bangladesh J. Fish. Res., 15-16: 27-36.

Kohinoor AHM, MM Rahman, J Rashid, P Chowdhury and MS Islam, 2018. Production potentials of pabda (Ompok pabda, Hamilton) in semi-intensive management under different stocking densities. Bangladesh J. Fish., 30: 37-45.

Komal W, Q Minahal, S Munir, S Fatima, R Liaqat and L Naseer, 2021. Role of water quality Parameters in pond management: A review. Int. J. Biosci., 18: 45-60.

Kostori FA, S Parween and MN Islam, 2011. Availability of small indigenous species (SIS) of fish in the Chalan Beel - the largest wetland of Bangladesh. Univ. J. Zool. Rajshahi Univ., 30: 67-72.

Kwasek K, AL Thorne-Lyman and M Phillips, 2020. Can human nutrition be improved through better fish feeding practices? a review paper. Crit. Rev. Food Sci. Nutr., 60: 3822-3835.

Li M, B Manning and E Robinson, 2004. Effect of daily feed intake on feed efficiency of juvenile channel catfish. N. Am. J. Aquac., 66: 100-104.

Makori AJ, PO Abuom, R Kapiyo, DN Anyona and GO Dida, 2017. Effects of water physico-chemical parameters on tilapia (Oreochromis niloticus) growth in earthen ponds in Teso North Sub-County, Busia County. Fish. Aquat. Sci., 20: 1-10.

Malakar AK, WS Lakra, M Goswami and RM Mishra, 2013. Genetic differentiation of Ompok bimaculatus (Teleostei: Siluridae) population based on mtDNA cytochrome b gene. Mitochondrial DNA, 24: 145-150.

Malla S and S Banik, 2015. Larval rearing of an endangered catfish, Ompok bimaculatus (Bloch, 1794) with live and artificial diets: A preliminary study in Tripura, India. Int. J. Fauna Biol. Stud., 2: 16-21.

Marimuthu K, H Palaniandya and ZA Muchlisin, 2019. Effect of different water $\mathrm{pH}$ on hatching and survival rates of African catfish Clarias gariepinus (Pisces: Clariidae). Aceh J. Anim. Sci., 4: 80-88.

Mohsin A, MN Islam, MA Hossain and SM Galib, 2012. Cost-benefit analyses of carp polyculture in ponds: a survey study in Rajshahi and Natore districts of Bangladesh. Bangladesh J. Environ. Sci., 23: 103-107.

Mondal S, A Wahab, BK Barman and A Al-Asif, 2020a. Enhance the contribution of small indigenous fish production: Emphasis mola (Amblypharyngodon mola) with carps in North-West of Bangladesh. Singapore J. Sci. Res., 10: 308-316.

Mondal S, A Wahab, BK Barman and A Al-Asif, 2020b. Breeding biology of mola carplet, (Amblypharyngodon mola, Hamilton, 1822) in semi-natural condition. Asian J. Anim. Sci., 14: 111-120.

Mota VC, J Hop, LA Sampaio, LTN Heinsbroek, MCJ Verdegem, EH Eding and JAJ Verreth, 2018. The effect of low pH on physiology, stress status and growth performance of turbot (Psetta maxima L.) cultured in recirculating aquaculture systems. Aquac. Res., 49: 3456-3467.

Muya JW and JO Manyala, 2015. Comparison of the growth performance and economic viability of four marine 
fish species under cage culture on the south coast of Indian Ocean. Agric. Biol. Sci. J., 1: 177-182.

Nahar N, S Afrin, MI Hossain, MA Samad, FB Farhad and Rahman ML, 2021. Influence of stocking density on growth performance of Labeo bata in cage at river Padma, Rajshahi, Bangladesh. Asian J. Fish. Aquat. Res., 11: $1-11$.

Nahar S and MA Halim, 2019. Study the growth performance of Ompok pabda (Hamilton 1822) in cemented dewatering canal at Bapard campus, Gopalgonj. J. Entomol. Zool. Stud., 7: 935-939.

Naylor RL, RW Hardy, AH Buschmann, SR Bush, L Cao, DH Klinger, DC Little, J Lubchenco, SE Shumway and M Troell, 2021. A 20-year retrospective review of global aquaculture. Nature, 591: 551-563.

Ndome CB, AO Ekwu and AA Ateb, 2011. Effect of Feeding frequency on feed consumption, growth and feed conversion of Clarias gariepinus X Heterobranchus longifilis hybrids. Am. J. Sci. Res., 6: 6-12.

Noeske-Hallin TA, RE Spieler, NC Parker and MA Suttle, 1985. Feeding time differentially affects fattening and growth of channel catfish. J. Nutr., 115: 1228-1232.

Nölle N, S Genschick, K Schwadorf, H Hrenn, S Brandner and HK Biesalski, 2021. Correction to: Fish as a source of (micro)nutrients to combat hidden hunger in Zambia. Food Security, 12: 1385-1406

Razeim A, G Farouque, A Sarker, A Al-Asif and M Ahmed, 2017. Attitude of farmers towards Pangas farming for their livelihood improvement. Asian-Austra. J. Biosci. Biotech., 2: 106-119.

Paul B, Chanda S and Giri S, 2014. Effect of feeding frequency on growth performance of Ompok pabda fry. Indian J. Anim. Nutr., 31: 200-202.

Prabhu PAJ, JW Schrama and SJ Kaushik, 2016. Mineral requirements of fish: A systematic review. Rev. Aquac., 8: 172-219.

Purkayastha S, S Sarma, UK Sarkar, WS Lakra, S Gupta and SP Biswas, 2012. Captive breeding of endangered Ompok pabda with Ovatide. J. Appl. Aquac., 24: 42-48.

QGIS Development Team, 2019. QGIS geographic information system, GNU GPLv2.

Rahman H, JA Mirza, A Hossain, A Al-Asif, E Haq, P Chwakravorty and M Rahman, 2017. Economics of fish production in paddy fields in Bangladesh. Asian J. Med. Biol. Res., 3: 379-390.

Rahman MA, A Arshad and SMN Amin, 2012. Growth and production performance of threatened snakehead fish, Channa striatus (Bloch), at different stocking densities in earthen ponds. Aquac. Res., 43: 297-302.

Reeves RR, BD Smith and T Kasuya, 2000. Biology and conservation of freshwater Cetaceans in Asia, IUCN Species Survival Commission No. 23. The Nature Conservation Bureau Ltd, Newbury, UK, Oxford, UK.

Reigh RC, MB Williams and BJ Jacob, 2006. Influence of repetitive periods of fasting and satiation feeding on growth and production characteristics of channel catfish, Ictalurus punctatus. Aquaculture, 254: 506-516.

Reksten AM, T Somasundaram, M Kjellevold, A Nordhagen, A Bøkevoll, LM Pincus, AAM Rizwan, A Mamun, SH Thilsted, T Htut and I Aakre, 2020. Nutrient composition of 19 fish species from Sri Lanka and potential contribution to food and nutrition security. J. Food Compos. Anal., 91: 103508.

Roos N, MM Islam and SH Thilsted, 2003. Small indigenous fish species in Bangladesh: Contribution to vitamin A, calcium and iron intakes. J. Nutr., 133: 4021S-4026S.

Roy D, AK Sarker, AMMK Abedin, S Sarker, KN Begum, GA Latifa, 2021. Some biological aspects of cultured Ompok pabda (Hamilton, 1822) collected from a local fish farm in Mymensingh, Bangladesh. Aquac. Stud., 21: 149-159.

Samad A and AM Imteazzaman, 2019. Growth and production performance of indigenous threatened cat fish, Clarias batrachus ( Linn . 1758 ) based on stocking density in North Western Bangladesh. Int. J. Fish. Aquat. Stud., 7: 267-274.

Samad A, M Rahman and AK Paul, 2019. Growth and production of riverine Catla catla (Hamilton, 1822) fry in pond habitat based on stocking density. Int. J. Fish. Aquat. Stud., 5: 414-419.

Samad M and A Bhuiyan, 2017. Stocking density of threatened cat fish Heteropneustes fossilis (Bloch, 1792) in seasonal ponds of Rajshahi, Bangladesh. Bangladesh J. Sci. Ind. Res., 52: 253-262.

Samad M, M Farjana, S Chatterjee, M Rahman and S Barman, 2017. Culture technique of endangered Notopterus chitala (Hamilton, 1822) with Oreochromis niloticus for domestication in pond habitat. Bangladesh J. Sci. Ind. Res., 52: 187-194.

Samad M, M Rasid, M Haque, A Paul and H Ferdaushy, 2016. Density-dependent growth of endangered Labeo bata (Hamilton, 1822) in Nursery Ponds. J. Environ. Sci. Nat. Resour., 9: 67-73.

Samad MA, EJ Alice and D Pal, 2021. Effect of different dietary protein level on growth, production and survivability of threatened Mystus cavasius (Hamilton-Buchanan 1822) in pond habitat. Asian J. Med. Biol. Res., 6: 659-673.

Samad MA, MY Arafat, H Ferdaushy, SK Chatterjee, AK Paul and MM Rahman, 2017. Density based sustainable fingerling production techniques of indigenous major carp, Labeo rohita (Hamilton, 1822) in 
ponds of Bangladesh. J. Biosci. Agric. Res., 12: 968-975.

Samad MA, A Imteazzaman, MI Hossain and MS Reza, 2014. Effects of three different low cost feeds on growth performance of walking catfish (Clarias batrachus L.) in earthen ponds. Rajshahi Univ. J. Life Earth Agric. Sci., 42: 1-10.

Samad MA, MA Islam and MA Khaleque, 2005. Effect of stocking density on the growth and survival rate of Magur (Clarias batrachus) fry in laboratory and nursery ponds. Pakistan J. Biol. Sci., 8: 338-344.

Samad MA, M Lutfunnahar, SK Chatterjee, M Ashrafuzzaman and MS Reza, 2017a. Effect of stocking density of fingerlings production of Black carp Mylopharyngodon piceus (J. Richardson, 1846) in pond condition. Res. Agric. Livest. Fish., 4: 37-44.

Samad MA, M Nahiduzzama, M Ashrafuzzaman, MA Rashid and M Akter, 2017b. Culture of indigenous catfish Shingi, Heteropneustes fossilis (Bloch, 1794), with available low cost formulated feed in earthen ponds of Bangladesh. J. Coast. Life Med., 5: 288-292.

Samad MA, BS Rahman, A Al-Asif, and RK Audhikary, 2013. Availability and potentiality of small indigenous species of fish throughout the tear in South-Western region of Bangladesh. African J. Basic Appl. Sci., 5: 167-173.

Shajib, MSH, B Sarker, A Al-Asif, MM Rahman, MA Zafar and A Hossain, 2018. Effects of stocking density on the growth rate of gold fish fry reared in hapa. Asian J. Med. Biol. Res., 3: 504-515.

Shamsuzzaman MM, MM Islam, NJ Tania, MA Al-Mamun, PP Barman and X Xu, 2017. Fisheries resources of Bangladesh: Present status and future direction. Aquac. Fish., 2: 145-156.

Sharma JG and R Chakrabarti, 1999. Larval rearing of common carp Cyprinus carpio: A comparision between natural and artificial diets under three stocking densities. J. World Aquac. Soc., 30: 490-495.

Singh P, SK Nayak and D Reang, 2017a. A study on growth performance and survivability of Ompok pabda (Hamilton 1822) fingerlings in earthen pond fed with different feed ingredients. Int. J. Fish. Aqua. Stud., 5: 289-294.

Singh, P., Sunil Kumar Nayak, Reang, D., Singh, R., 2017b. To study the Survivavility of Ompok pabda (Hamilton 1822) fingerlings fed with different ingredients under earthen ponds like, rice bran, mustard oil cake, fish meal and floating feed. Int. J. Fish. Aquac. Sci. 7: 23-32.

Slembrouck J, E Baras, J Subagja, LT Hung and M Legendre, 2009. Survival, growth and food conversion of cultured larvae of Pangasianodon hypophthalmus, depending on feeding level, prey density and fish density. Aquaculture, 294: 52-59.

Soler P, M Faria, C Barata, E Garcia-Galea, B Lorente and D Vinyoles, 2021. Improving water quality does not guarantee fish health: Effects of ammonia pollution on the behaviour of wild-caught pre-exposed fish. PLoS One, 16: 1-17.

Stavrescu-Bedivan MM, GV Scaeteanu, RM Madjar, MS Manole, AC Staicu, FT Aioanei, EF Plop, GL Toba and CG Nicolae, 2016. Interactions between fish well-being and water quality: A case study from MoriiLake area, Romania. Agric. Agric. Sci. Procedia, 10: 328-339.

White PG, 2013. Environmental consequences of poor feed quality and feed management, in: FAO Fisheries and Aquaculture Technical Paper No. 583. Rome, FAO. pp. 553-564.

Wilkie MP and CM Wood, 1996. The adaptations of fish to extremely alkaline environments. Comp. Biochem. Physiol. B Biochem. Mol. Biol., 113: 665-673.

Zafar MA, MZ Hasan, MM Ali, and A Al-Asif, 2017. Growth and production performance of Vietnamese koi (Anabas testudineus) with Magur (Clarias batrachus) at different stocking densities. Asian-Australasian J. Biosci. Biotechnol., 2: 226-237.

Zakęś Z, A Kowalska, S Czerniak and K Demska -Zakęś, 2006. Effect of feeding frequency on growth and size variation in juvenile pikeperch, Sander lucioperca (L.). Czech J. Anim. Sci., 51: 85-91.

Zaman FU, MA Samad, A Islam, HU Jaman, S Khondoker and A Al-Asif, 2017. Assessment of sustainability of Pangasius (Pangasius hypophthalmus) farming at Jhikargachha upazila in Jessore district, Bangladesh. Int. J. Fauna Biol. Stud., 4: 109-119. 